\title{
Optimising the yield of Douglas-fir with an appropriate thinning regime
}

\author{
Jean-Philippe Schütz • Peter Lukas Ammann • \\ Andreas Zingg
}

Received: 16 October 2014/Revised: 12 December 2014/ Accepted: 12 January 2015/Published online: 28 January 2015

(C) Springer-Verlag Berlin Heidelberg 2015

\begin{abstract}
Aim of this study was to determine the longterm effects of thinning regime with different intensities on the stand and tree social classes development, particularly regarding the old question of compensative effect between stocking and girth improvement using the example of Douglas-fir. Data provide from a thinning experiment in one site of Swiss Central Plateau, from age 11 until 41 years containing six treatment variants (three planting densities and two level of stand density) repeatedly measured six times, as well as from seven permanent yield plots times series aged between 17 and 127 years. We present as well the real observed characteristics in term of stem numbers distribution, diameter increment per d.b.h. categories, as results from simulation over the whole production time until 105 years with an appropriate growth simulator, in terms of net value increment (MAIv). Our results show that the effect of thinning works mainly on the social medium categories, in terms of number and girth improvement. Social dominant trees are more or less untouched by thinning, demonstrating that there are in every stand a quite important number of self-dominating trees which do not need particular silvicultural help to maintain their dominant status in the upper storey. The
\end{abstract}

Communicated by Aaron R Weiskittel.

J.-P. Schütz $(\bowtie)$

Department Environmental Systems Science, ETZ Zürich,

Brüggliäcker 37, 8050 Zurich, Switzerland

e-mail: jph.s@bluewin.ch

P. L. Ammann

Swiss Silviculture Competence Center, 3250 Lyss, Switzerland

A. Zingg

Swiss Federal Research Institute WSL, 8093 Birmensdorf, Switzerland expected compensation between stem number reduction and girth improvement shows that the remaining stand density is determinant on the net value level. The so-called mass effect seems really more effective. The best way to improve a stand value appears to be artificial pruning. Because a thinning regime should not consider only the economic productivity but take in account risk, stability and resilience and particularly the way of renewal, we suggest a way for optimising the thinning regime combining effect of biological rationalisation and risks.

Keywords Optimal thinning - Yield productivity . Rotation · Douglas-fir · Pruning · Plenterring

\section{Introduction}

Regularly applied thinning is one of the most common silvicultural interventions, at least in temperate Central Europe. Historically, thinning was first conceived as the advance harvesting of trees which would otherwise have been likely to die out because of overcrowding. This led, particularly in German silviculture to so-called thinning from below concepts, where essentially socially low individual trees are removed. Another thinning concept, top thinning, where taller trees are removed, coupled with vigourous interventions, was proposed in the wake of the Reventlow (1801) trials, particularly for broadleaved tree species, like beech, and has been practised since then by the French silviculture school (Broillard 1901). Thus the way to apply thinning has long varied in terms of both the kind and degree of intervention. Some favour early heavy thinning (Bastien 1997; Wilhelm and Rieger 2013), whereas others prefer moderate thinning to maintain enough whole stand biomass (Utschig 2002) and use a so- 
called mass effect. The dilemma of thinning is to find a balance between maintaining enough stumpage and creating added value by selecting the best timber and encouraging diameter growth by regulating the spacing between trees.

A paradigm change in thinning principles came with Schädelin's (1926, 1934) selective thinning proposal. Here thinning is considered as an intervention to improve stand development coupled with selective effects to enrich the yield by improving the quality. Thus thinning aims at ensuring the growth of the best trees. From a biological and silvicultural point of view, such nurturing interventions should be applied often and moderately, from an early stage on, in order to make use of the ability of young trees to adapt to more space. Such operations, e.g. in the early pole stage, are, however, very expensive even when performed mechanically. Whether such investment is profitable in the long run can only be assessed by comparing a model of the stand development with a growth simulator sensitive to spacing. As a reaction to increasing tending costs, ways of reducing these costs have been proposed based on so-called biological rationalisation (Schütz 1999a, b, 2003, 2006; Ammann 2004, 2013), where natural dynamic processes like social self-differentiation are promoted through very spatially specific (situative) operations in which competition is only controlled around the future crop trees. Such socalled situative selective thinning could be performed with very simple methods like girdling (Roth et al. 2001) or simple slant cuts of the competitors, where they are then left standing and not extracted. These methods should be used preferentially in the phase before commercial thinning is possible. They allow to substantially reduce costs about 5-10 times in comparison with the more usual motor-manual tending of the full area (Schütz 2006).

Nowadays, it is wise to enlarge the thinning concept, taking into consideration its effects on stability, particularly during the trees' sensitive phase of development when they can be damaged by lasting snow (Ivanov 2007) or by storms in the early phase of regeneration (Vanomsen 2006; Knoke 1998). Thinning can also improve ecological amenities through allowing more light to penetrate the stand (Bailey and Tappeiner 1998). A thinning regime should not only consider the development of one cohort, but also of the following generation and the strategic objectives for a stand's renewal, considering that clear cut is no more justifiable as a general silvicultural system.

To optimise the thinning regime, the following questions should be considered:

- For which tree social classes do repeated thinning boost diameters sufficiently to increase the net value?

- Is there a productivity optimum between stumpage reduction and net timber value?

\section{Materials and methods}

These questions are addressed in this paper using data from a thinning trial installed in 1977 in an 11-year-old Douglasfir plantation in Neuendorf (Swiss Central Plateau). At the time of the last inventory (2007), the stand was 41 years old, which is old enough for demonstrating some effects of different thinning treatments on growth and yield during the main phase of silvicultural interventions, but too short to address the long-term effects of thinning. Data from seven long-term repeatedly measured yield plots, some more than 100 years old, were included to calibrate a growth simulator developed previously for other tree species (Schütz and Zingg 2007).

The thinning trial characteristics

The thinning trial in Neuendorf, situated $47^{\circ} 16^{\prime} 56^{\prime \prime} \mathrm{N}$; $7^{\circ} 49^{\prime} 47^{\prime \prime} \mathrm{E}$, was designed as a split plot with $3 \times 2$ treatments, starting with three different planting densities $(2,790,1,966$ and 1,346 trees/ha), and leading at trial end at about 50 years to two different densities with SDI of 0.73 , respectively, 0.52 (blocks). Every treatment is replicated three times, with thus 18 plots of about 0.1 ha size each. The trial was set up 1977 in an 11-year-old Douglas-fir [Pseudotsuga menziesii (Mirb) Franco] plantation. All trees were tagged and measured for their d.b.h. (at $1.3 \mathrm{~m}$ height, nearest $1 \mathrm{~mm}$ ). In a subsample (between 80 and 130 stems per variant), the total height, height to lowest live branches and four crown radii were recorded to the nearest $0.1 \mathrm{~m}$. Re-measurements were carried out six times in 1981 (age 15 years), 1986 (20), 1991 (25), 1996 (30), 2001 (35) and 2007 (41). Each measure included a thinning intervention, such as selective thinning (according to Schädelin), varying in intensity depending on the trial guide lines.

Site conditions The site is on the Swiss Central Plateau at an altitude of $455 \mathrm{~m}$ a.s.l., where the mean temperature is $8.2^{\circ} \mathrm{C}$, the period of vegetation 205 days and the geological substrate moraine. The soil consists of deep and productive cambisols, and precipitation is about $1,150 \mathrm{~mm} /$ year.

The stand development growth model

The second of our main goal aims at the long-term yield effect of thinning, possibly until completion of the production cycle, can only be addressed by modellisation with a simulator sensitive to stand density differences. We assumed here that growth variation (diameter increment) depends more on the social position of a tree and less on variations in the site conditions. As growth can vary greatly between and within categories, we opted for a categorical 
model of growth and development analysis as exemplified by the growth model SiWaWa (see http://www.siwawa. org) used in, e.g. Schütz and Zingg (2007, 2010). To calibrate this categorical simulator which is independent of distance, sufficient numbers of trees are needed in the different social categories. We, therefore, merged the data from the single replications (plots around 0.1 ha in area), resulting in a plot of around 0.3 ha for each variant. In this model, gcum, i.e. the cumulative basal area of d.b.h. categories larger than the category under consideration, is used as the main explanatory variable to express the density and social position. It is also referred to as the overtopping basal area or basal area of larger trees (BAL) according to Wykoff et al. (1982) and Wykoff (1990).

Additionally, seven long-term yield plots series of Douglas-fir pure stands were considered, aged between 17 and 127 years (Table 1) resulting altogether in 82 measurements and 75 periods of increment. The measurements were as described above, except that the d.b.h. threshold was set at $8 \mathrm{~cm}$ and fewer height measurements (20-45) were made.

To modelise the stand development correctly, the main functions needed are: (a) maximum stand density to determine youth mortality due to overcrowding; (b) diameter increment sensitive to stand density to determine number of stem shifting their diameter class, and (c) the thinning mode, i.e. the distribution of removed trees. Several allometric functions are also required, such as a volume function, a taper function to determine assortments, as well as economic data such as the cost of harvesting and timber prices.

Maximum stand density and overcrowding mortality (first grade mortality)

The relation stem numbers $N$ to mean quadratic diameter $d_{\mathrm{g}}$ as $\ln (N): \ln \left(d_{\mathrm{g}}\right)$ (Reineke 1933) is widely used as a guideline for maximum stand density (Schütz and Zingg 2007; Pretzsch and Biber 2005; Drew and Flewelling 1979).
Since our study site's contain no un-thinned plots, we used data from the data-community LOGS (Pacific NW-Coast $\mathrm{N}$-America), where thinning trials very similar in design and approach have been established (Curtis et al. 1977), in each case with un-thinned control variants. We used the curvature parameter $\beta 1$ and $\gamma 1$ of the smoothed function according to function $N=\alpha e^{\beta 1 \ln (d)+\gamma 1(\ln (d))^{2}}$ of the yield table for natural regeneration (Curtis et al. 1982), transformed in order to pass through the first point of the maximum observed $N: d_{\mathrm{g}}$ to determine the parameter $\alpha$ analytically (Fig. 1). The plot longest observed, Küssnacht SZ, Schlittenried, was considered as representing the average yield level (YL 1.0). When this yield plot was established at age 41 , we obtained a sufficiently reliable estimate of previous thinning by counting the removed stumps to locate the $N: d_{\mathrm{g}}$ curve correctly (Schütz and Zingg 2007).

$N=\alpha e^{\beta 1 \ln (d)+\gamma 1(\ln (d))^{2}}$

Parameter values, see Table 2. Goodness of fitting in Table 3.

A similar way of estimating $N_{\max }$ (stem numbers of unthinned plots), using the so-called stochastic frontier analysis methodology, was used by Charru et al. (2012) for Douglas-fir in France with data from the National Inventory.

According to the generally accepted view in Reineke's (1933) sense, mortality is the proportion of the basal area $(G)$ exceeding the $N: d_{\mathrm{g}}$ borderline for maximum density. The conventional view is that this mortality will affect the lowest social classes. A detailed analysis of the LOG data (particularly the study at Hoskins), however, showed that first grade mortality varies between $d_{\min }$ and $d_{\mathrm{g}}$, and can be fitted with a Weibull distribution with parameters $\alpha 2=d_{\min } ; \quad \beta 2=\left(-0.026975+1.03673 \quad d_{\text {gmort }}\right)-\alpha 2 ;$ $\gamma 2=2.5497-1.0169 d_{\text {gmort }}$; where $d_{\text {gmort }}$ is the quadratic mean diameter of the mortality. Thus $d_{\mathrm{gmort}}=\left(d_{\mathrm{g}}-d_{\mathrm{min}}\right) /$ $2+d_{\min }$.

Table 1 Characteristics of the seven yield plots

\begin{tabular}{llllcc}
\hline Plot number & Location & $\begin{array}{l}\text { Elevation } \\
\text { (a.s.1.) }\end{array}$ & $\begin{array}{l}\text { Measurement } \\
\text { periods }\end{array}$ & $\begin{array}{l}\text { Number } \\
\text { of surveys }\end{array}$ & $\begin{array}{l}\text { Age } \\
\text { range }\end{array}$ \\
\hline $26-001$ & Biel & 600 & $1906-1965$ & 11 & $\begin{array}{l}\text { Surface } \\
\text { area (ha) }\end{array}$ \\
$26-002$ & Biel 2 & 620 & $1906-1932$ & 6 & 0.09 \\
$26-003$ & Küssnacht SZ & 610 & $1924-76$ & $25-51$ \\
$26-004$ & Montagny & 620 & $1926-1962$ & 15 & $41-127$ \\
$26-005$ & Le Mont s Lausanne & 750 & $1926-2012$ & 15 & 0.5 \\
$26-006$ & Vernand-Dessous & 580 & $1938-2011$ & 13 & $22-58$ \\
$26-007$ & Risch ZG & 490 & $1929-2002$ & 13 & $38-111$ \\
Total & & 82 & & & 0.2 \\
\end{tabular}


Diameter increment function $i_{\mathrm{d}}$

This is the core function of the simulator. As in previous studies with the growth simulator SiWaWa, we used the following functional approach (2) because it is simple and the parameters are reliable to stand characteristics,

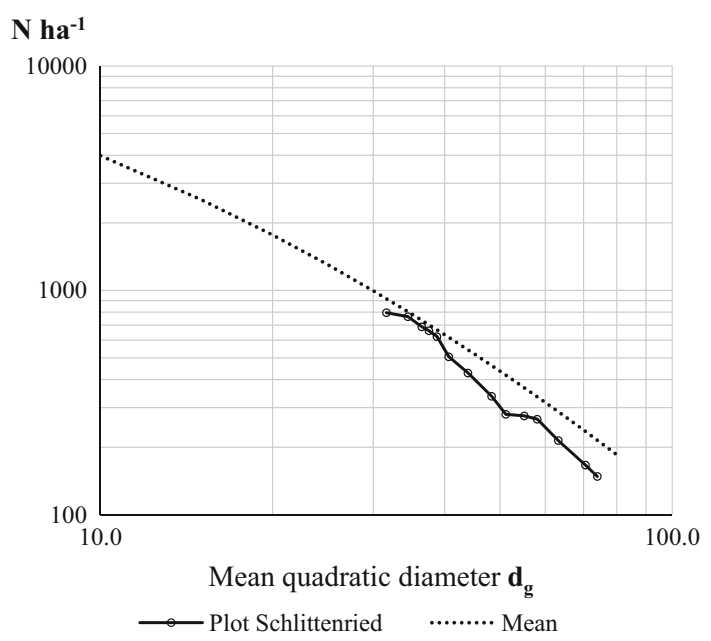

Fig. 1 Determining the maximum stand density line. The curve of a known maximum stand density model (Curtis et al. 1982) is translated through an early estimate of the maximum density of a yield plot. Here the plot is considered to have a mean yield level $i_{d}=\alpha 3+\beta 3(\text { gcum })^{\gamma 3}$

where $\alpha 3$ represents the intercept with the $y$-axis or the diameter increment of the dominant trees; $\beta 3$ is functionally related to the $x$-axis intercept or to the point of increment extinction, and $\gamma 3$ represents the intensity of the increment decrease. The explicative variable gcum or the basal area of stems larger than the considered category represents the social positional density within the stand, as well as generally. This variable has been found to be very relevant for sequentially estimating the diameter increment in both even-aged and plenter stands (Schütz 1975).

For each increment period, parameters $\alpha 3_{i}, \beta 3_{\mathrm{i}}$ and $\gamma 3_{\mathrm{i}}$ were fitted with classical nonlinear regression techniques. Analysing increments over a long-term period presents two problems: (1) they may vary greatly due to varying climatic conditions during the different measurement periods, and (2) increment losses occur due to biotic injuries. The first three measurement series were heavily affected by the Swiss needle cast [Phaeocryptopus gaeumannii (T. Rohde) Perak] during the 1960s and the six increment periods affected had to be eliminated in our analysis. The parameter $\alpha 3$ of function (2) was corrected by a dendrochronological index abbreviated as DRO (Schütz and Zingg 2007) to liberate the increment from the climatic effect. The result is an average climatic increment value, which can be

Table 2 Parameters values for the different functions

\begin{tabular}{lllccl}
\hline Function & $\alpha$ & $\beta$ & $\gamma$ & $\delta$ & \\
\hline 1 & 13,200 & -0.01822025 & -0.2180693 & & \\
3 & 18.827704 & -2.306864 & -4.342249 & & \\
4 & 10.140829 & 1.095128 & -11.9718 & -0.89412 & \\
5 & 2.966351 & -1.234994 & 0.0078926 & & \\
7 & -11.057 & 5.312 & & & \\
8,9 & 5.550417 & 0.635298 & 895.767857 & -1.829879 & 0.0726674 \\
10 & 0.0000640157 & 2.128416 & -0.052317 & 0.615522 & 0.000122359 \\
11 & 1.080409 & -0.952037 & 0.803164 & -0.93976 & -0.00002573234 \\
12 & 0.99558 & -0.772914 & -0.921808 & 0.696707 & \\
13 & 0.4724 & 0.1134 & & & \\
\hline
\end{tabular}

Table 3 Goodness of fit for the different functions

The goodness of fit of the regression analysis is expressed in terms of the coefficient of determination $R^{2}$ and of the t-statistic of the standard partial coefficient of fitting and the corresponding p-tail of the transgression probability $\left(p_{i}\right)$

\begin{tabular}{lllllllll}
\hline Function & $R^{2}$ & $N$ & \multicolumn{7}{c}{$p_{i}$ for the corresponding parameter } \\
\cline { 4 - 8 } & & & $\alpha$ & \multicolumn{1}{l}{$\beta$} & $\gamma$ & $\delta$ & $\varepsilon$ & $\phi$ \\
\hline 3 & 0.696 & 109 & $<0.0001$ & $<0.0001$ & $<0.0001$ & & & \\
4 & 0.922 & 176 & $<0.0001$ & $<0.0001$ & $<0.0001$ & $<0.0001$ & & \\
5 & 0.253 & 191 & $<0.0001$ & $<0.0001$ & 0.0017 & & & \\
7 & 0.873 & 110 & & & & & & \\
10 & 0.985 & 600 & $<0.0001$ & $<0.0001$ & 0.0118 & 0.0192 & 0.0866 & \\
11 & 0.999 & 1,359 & $<0.0001$ & $<0.0001$ & $<0.0001$ & $<0.0001$ & 0.0889 & 0.0347 \\
12 & 0.998 & 1,359 & $<0.0001$ & $<0.0001$ & $<0.0001$ & $<0.0001$ & & \\
\hline
\end{tabular}


coupled for other uses with the dendrochronological index to simulate the effect of climate change. Such models can thus be considered to be highly climate sensitive.

The parameters $\alpha 3, \beta 3$ and $\gamma 3$ for the general $i_{\mathrm{d}}$ function can be estimated with the functions (3), (4) and (5):

$\alpha 3=\alpha 4+\beta 4 \ln (A)+\gamma 4 \mathrm{SDI}$,

where $A$ is age and SDI the stand density index ( $G_{\text {observed }} /$ $\left.G_{\text {max }}\right)(G=$ basal area).

Here both parameters $\beta 4$ and $\gamma 4$ are statistically significant with $p_{i}$ values $<0.0001$.

$\mathrm{INT}=\alpha 5+\beta 5 G+\gamma 5 \mathrm{SDI}+\delta 5\left(d_{\mathrm{dom}}-d_{\mathrm{g}}\right) ;$

where INT is the intercept with the $x$-axis, $d_{\text {dom }}$ the mean diameter of the 100 larger trees per ha. It implicitly contains the coefficient $\beta 3$, but is more explicit from the point of view of functionality and interpretation. $\beta 3$ can be deduced as $-\alpha 3 / \mathrm{INT}^{\gamma 3}$.

The goodness of fit is $R^{2}=0.922$, which is impressively high $(N=176)$. It can be explained by the fact that this intercept is very closely related to the stand density, which is, at the same time, the point of extinction of the increment. The three descriptors, $\beta 5, \gamma 5$, and $\delta 5$ are significant with $p_{i}$ values $<0.0001$.

$\gamma 3=\alpha 6+\beta 6 \mathrm{SDI}+\gamma 6 d_{\mathrm{g}}$

The goodness of fit is $R^{2}=0.253(N=191)$, which is less satisfactory but not so influential given the fact that the two axis intercepts are more important.

Note that, when simulating with the single $d$ distribution (list of $d$ ), gcum should be adjusted by adding $2 \mathrm{~cm}$.

\section{Distribution of the thinning}

The points about $i_{\mathrm{d}}$ representativeness in long-term series discussed above also apply to modelling thinning interventions. The kind of interventions we intend to model should correspond to a thinning practice applied actually, or at least recommended from a silvicultural point of view. As discussed in the introduction, the selective thinning (according to Schädelin 1934) is generally accepted to be the kind of thinning most valuable today, assuming a fixed number of crop trees (Z-trees according to Abetz 1975). It was introduced in Switzerland in the 1950s. Interventions in the thinning trial in Neuendorf applied a classical selective thinning, but in the yield plots before the 1960s rather thinning from below was used. The periods up to the 1960s were therefore eliminated, as were the periods when trees were badly injured by the Swiss needle cast. This left a relatively small number of suitable interventions, but enough to test the best approach.

The distribution of the thinnings observed was bi-modal (Fig. 2), probably because of collateral damage from harvesting. This affected slender and suppressed stems more than taller and stronger stems.

If the thinning is divided into two parts, an appropriate estimate can be attained. In the lower part, we observed a very clear, regular and constant decrease of about $10 \%$ in the stem numbers per $\mathrm{cm}$ in all interventions. This can be simply modelled. The upper part, which is more determinant because it affects trees in the upper storey, can be modelled with a Weibull distribution function, which can be fitted relative to the characteristic points of the main distribution. Its most sensitive indicator is $d_{\text {ge }}$ (the quadratic mean diameter of removal). The relationship $d_{\mathrm{ge}}$ to $d_{\mathrm{g}}$, known as the Hiley thinning factor (Hiley 1956), characterises the thinning type and remains quasi invariant in our case at least the selective thinning type with an average value of 1.027. Another decisive point is $d_{\text {maxe }}$ (the maximum diameter of removal):

$d_{\operatorname{maxe}}=d_{\max }-\left(-1.6027+0.2132 d_{\mathrm{g}}\right)$

$\gamma \mathrm{We}($ coefficient of the Weibull distribution of removal $)=$ $4.3538-0.5652 \ln \left(d_{\mathrm{g}}\right), \beta \mathrm{We}=-3.0171+4.8696 \ln \left(d_{\mathrm{g}}\right)$.

Determination of height

In a previous paper (Schütz and Zingg 2010), we explained why we consider the classic way of assessing a site's productivity with the so-called site index $\left(H_{\mathrm{dom}}\right.$ at 50 years, abbreviated as $\mathrm{BON}$ ) to be less indicative than referring to the yield level (level of $G$ or $G_{\text {observed }} / G_{\max }$ ). Nevertheless, we need individual height measurements for the third dimension as it strongly affects estimations of, for instance, volume. The approach we use here involves determining the curvature of a single height

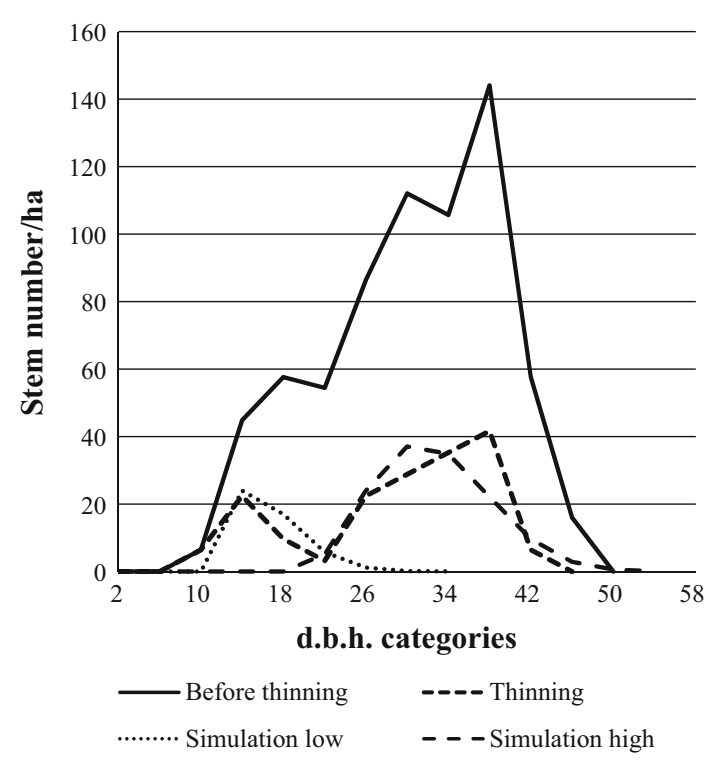

Fig. 2 Illustration of the bi-modal distribution of selective thinning in the thinning trial Neuendorf after 41 years in comparison to stem numbers per categories $(4 \mathrm{~cm})$ of the whole stand before thinning 
curve (7) by searching for the dependence of parameter $\beta_{7}$ at age $(A)$ and placing it in the $H_{\text {dom: }}$ :Age function (8):

$h_{i}=\alpha 7+\beta 7 \ln (A)$;

Goodness of such estimates is high $\left(R^{2}=0.873\right)$

$\beta 7=\alpha 8+\beta 8 \ln (A) ;$

The general site index function is taken from Bégin's (1992) yield table for Switzerland using the Payandeh (1974) and Newnham (1988) models:

$H_{\text {dom }}=\alpha 9 \mathrm{BON}^{\beta 9}\left[\left[\left(1-\left(K A^{A / 50}\right)\right)^{\gamma 9 \mathrm{BON}^{\delta 9}}\right]\right]$

$K=1-[\mathrm{BON} /(\alpha 9 \mathrm{BON} \beta 9)]^{(1 /(\gamma 9 \mathrm{BON}))^{\delta 9}}$

where BON is the site index.

\section{Volume}

We used the database of WSL (Swiss Federal Institute for Forest, Snow and Landscape research WSL, Birmensdorf, Switzerland) to obtain the values for the harvested stem volumes, measured at 2-m intervals (volume of the whole stem, without branches), and fitted them into the following volume function

$v=\alpha 11 e^{\left[\left(\beta 11 \ln (d)+\gamma_{11}(\ln (d))^{2}+\delta_{11} \ln (h)+\varepsilon 11(\ln (h))^{2}\right]\right.}$

Taper equations and timber assortments

Net merchantable production is a widely recognised measure of productivity. For this, the timber assortment must be determined, together with the corresponding selling prices and harvesting costs. The SiWaWa model produces, for each simulation step at 5-year intervals, the gross yield distribution in $4 \mathrm{~cm}$ d.b.h. categories for the remaining stumpage, as well as for removal. We used the following taper function, describing the relative diameter (drel) as dependent on d.b.h. and height (12), or describing the relative height (hrel) as dependent on diameter (13) (derived after Dagnélie et al. 1999 for Douglas-fir), to determine the corresponding timber products for each d.b.h. category:

$$
\begin{aligned}
\text { drel }= & \alpha 12+\beta 12 \text { hrel }+\gamma 12 \mathrm{hrel}^{2}+\delta 12 \mathrm{hrel}^{3} \\
& +\varepsilon 12 \mathrm{dhp}+\phi 12 \mathrm{dhp}^{2} \\
\text { hrel }= & \alpha 13+\beta 13 \mathrm{drel}+\gamma 13 \mathrm{drel}^{2}+\delta 13 \mathrm{drel}^{3}
\end{aligned}
$$

Double bark thickness (Bégin 1992)

bth $=\alpha 14+\beta 14$ d.b.h.

We assumed the proportion of merchantable products depend on a $\log$ end diameter of $30 \mathrm{~cm}$ (under bark) for medium-length stems and $20 \mathrm{~cm}$ for short logs $(5 \mathrm{~m})$. The remaining part is assumed to produce energy timber in chip form. Such a simplification corresponds with the current situation in the timber market in Switzerland. Each assortment was classified according to the Swiss trade practice for round wood (http://www.wvs.ch).

The harvesting strategies we considered use harvesters and forwarders for small logs, and motor-manual felling and skidder logging for medium-length timber. Harvest costs were determined with the software HeProMo (http:// www.wsl), assuming normal (easy) conditions (Frutig et al. 2009). The input variable is the mean volume of the logs. The labour and machine costs were based on the level in Switzerland in 2013, and the timber prices on the recommendations of the Forest Economy Association Canton Zurich (http://www.zueriwald.ch/holzmarkt/rundholz/), for L3/L2 and B-C (average) log quality (the letters correspond to usual timber quality classification in Europe) in the season 2013-2014. Douglas-fir log prices were CHF $50 / \mathrm{m}^{3}\left(€ 42 / \mathrm{m}^{3}\right.$ ) higher to than for spruce.

Determining the yield productivity

We calculated productivity on the basis of the net merchantable value of the standing crop, plus the net merchantable value of all products previously removed during thinning, divided by the actual age (so-called MAIv; main annual increment in value) relative to the actual price/cost level. We consider this to be a sufficiently relevant descriptor of the productivity. We did not include interest because labour costs and timber prices are, in the long run, more or less indexed to money depreciation.

\section{Results of the thinning trial}

The thinning trial in Neuendorf after five thinning interventions over 41 years shows that thinning influenced the total height, crown length, surface area of the crown and crown diameter to a partly statistically significant extent (details not given).

\section{Diameter increment}

Figure 3 depicts the distribution of the diameter increment $\left(i_{\mathrm{d}}\right)$ after 41 years as dependent on gcum. The clear effect of block density can be seen in the left part of the graph and a clear decrease (extinction of increment) towards the $x$ axis (intercept) in the right part. The close bundling of the curves explains why $G$ (the basal area) is such an excellent predictor of coefficient $\beta$ for these distributions. The differences in the distributions between the two blocks are statistically highly significant, but within the blocks hardly significant. 


\section{Stem number distribution}

Figure 4 illustrates the stem number distribution after 41 years and the difference between the two density blocks. What is remarkable is that the maximum diameter remains practically the same throughout the treatments. The most striking difference is that the number of stem differs, particularly in the median range around $d_{\mathrm{g}}$. This suggests that the mass effect has a more decisive influence than growth in girth, as we analyse in more depth below.

As a consequence, the mean quadratic diameter $d_{\mathrm{g}}$ differs significantly between the density blocks, but within the blocks, only the two extreme planting densities differ significantly. The invariance of $d_{\max }$ suggests that the difference $d_{\max }-d_{\mathrm{g}}$ could be a good predictor for estimating the silvicultural history of a stand.

\section{Real net value productivity}

Figure 5 shows the yield productivity really observed for the seven time series. Here the mean net merchantable value of Douglas-fir increases until they are about 90 years old. After that, the curves flatten out, indicating more leeway of the point of optimal productivity.

\section{Results of simulation}

Because the duration of the thinning trial Neuendorf is not long enough to address the long-term effect of thinning and because the yield plots present only one usual stand density, the only way to find out the long-term effect of stand density on yield productivity is simulation with the previous mentioned yield simulator SiWaWa.

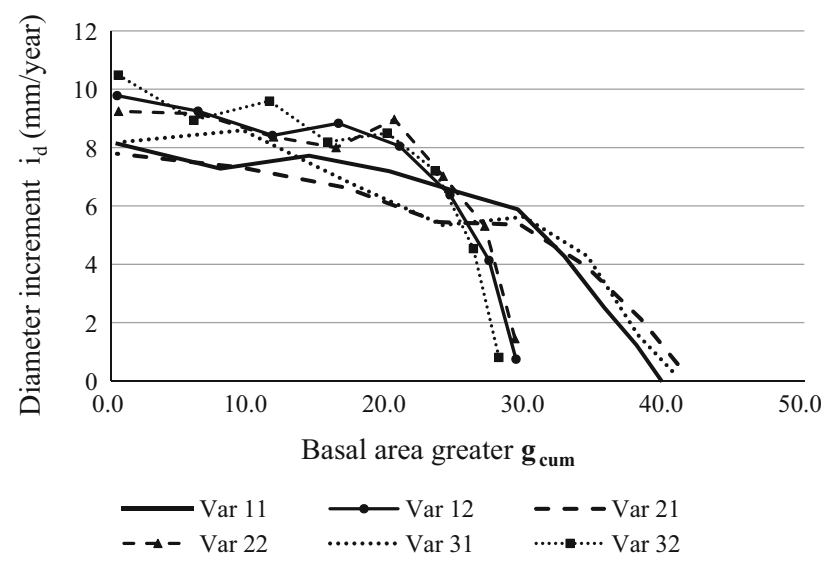

Fig. 3 Diameter increment $\left(i_{\mathrm{d}}\right)$ as dependent on the social position of the trees (gcum) after 41 years. Block 1 variants 11, 21, 31 (SDI 0.73 ); block 2: variants $12,22,32$ (SDI 0.52)

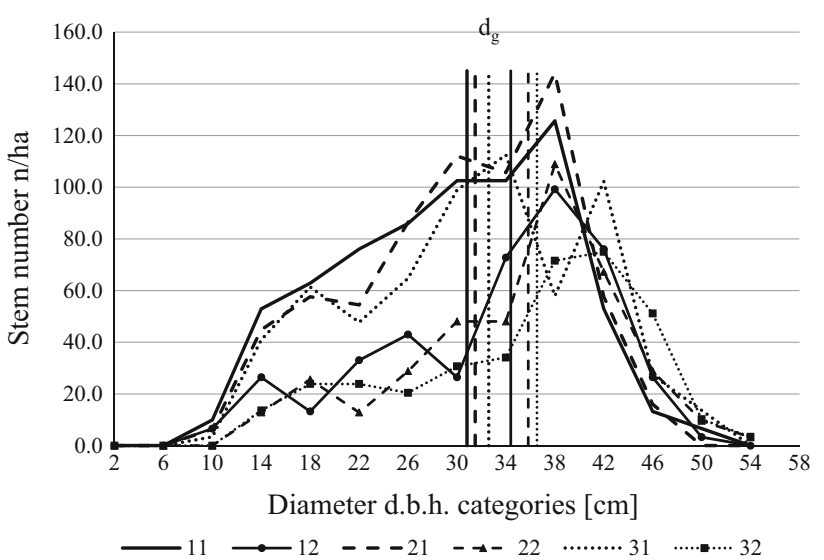

Fig. 4 Distribution of stem numbers per diameter categories $(4 \mathrm{~cm})$ after 41 years in the thinning trial Neuendorf according to the variants. Variants 11, 21, 31 correspond to moderate thinning (stand density index of the remaining stand 0.73 ), variants $12,22,32$ to heavy thinning (SDI 0.52), the first number corresponds to the different planting densities

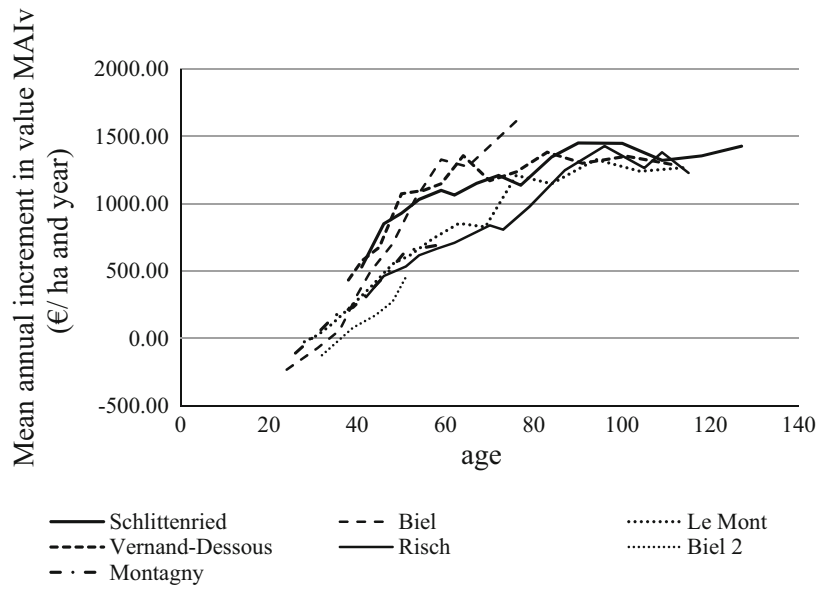

Fig. 5 Real observed MAIv in net value for the permanent yield plots

In a first set of simulations with the growth and yield simulator, we addressed the relationship between stand density and yield. We simulated seven thinning regimes with constant relative stand densities in terms of SDI, with thinning every 10 years from the age of 25 on until the age of 55 and every 15 years thereafter until 105 years (Fig. 6). The basal area between the interventions thus remained more or less constant. In the treatment "Control", i.e. "no thinning", the value of mortality is not considered because the timber was not commercialised. This leads to an early culmination at age 75 and a sharp decrease after that, whereas in thinned stands, the MAIv still increases until age 105, albeit with a rather flat curve. The net merchantable value of the mortality (not included in the MAIv) is as much as $€ 33,683$ at age 105 (or $30 \%$ of the value of the total removed timber). 
Figure 6 shows that the productivity is primarily dependent on the stand density. Clearly, the compensative effects of reducing the stem numbers do not have much impact, even on net value. The factor "mass effect" is more decisive.

The differences between the treatments variants are not very pronounced. Above a SDI of 0.75 , there are only moderate reductions in productivity (Fig. 7).

Another question is whether different spacing when the stand is established influences the productivity. The establishment costs which include the cost of plant materials, planting, fencing and cleaning can range widely, varying between $€ 16,524 / \mathrm{ha}, 11,508$ and $€ 7,967 /$ ha for the three different spacings (see above). Their importance for the whole production time should be relativised, as they represent between 12,8 and $6 \%$, respectively, of the total merchantable value at the end of the simulation. Another factor to be considered is that low spacing delays the moment of stand closure (at $d_{\mathrm{g}} 29,25$ and 20, respectively) and thus delays the timing of the first thinning. Simulation of the MAIv in the case of constant SDI 0.80 (Fig. 8) shows that the net value productivity is inversely proportional to the starting densities. The differences, however, are not very great $(95,100,99 \%$, respectively).

Artificial pruning as a measure for adding value

Differences in timber quality, due principally to how coarse branching is, have not yet been considered. It is, however, particularly relevant for Douglas-fir, which is a species that retains its branches for a very long time until sometimes self-pruning occurs. Artificial pruning sufficiently early (pole stage) on a sufficient number of future trees (crop

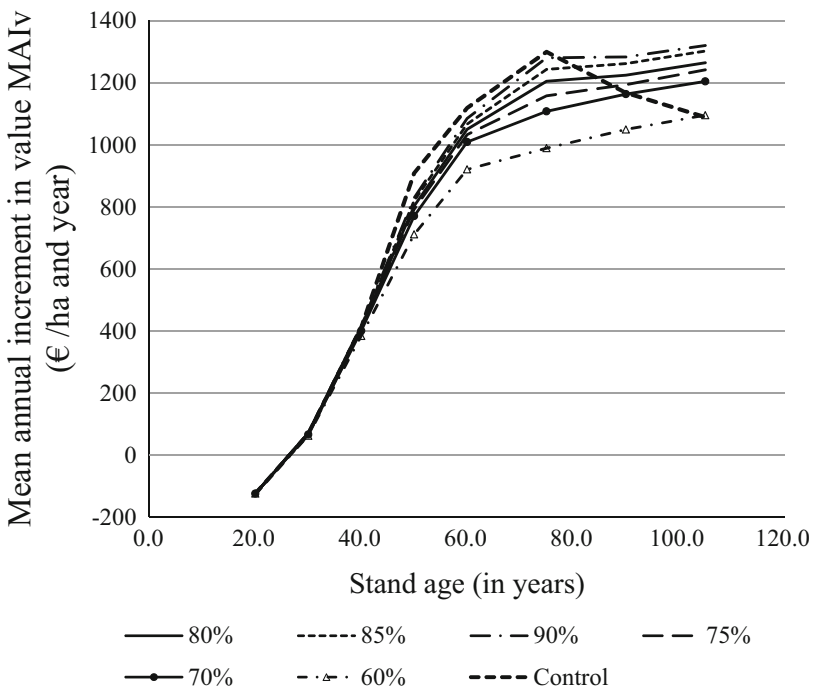

Fig. 6 Simulated mean net value (MAIv) for different constant stand densities

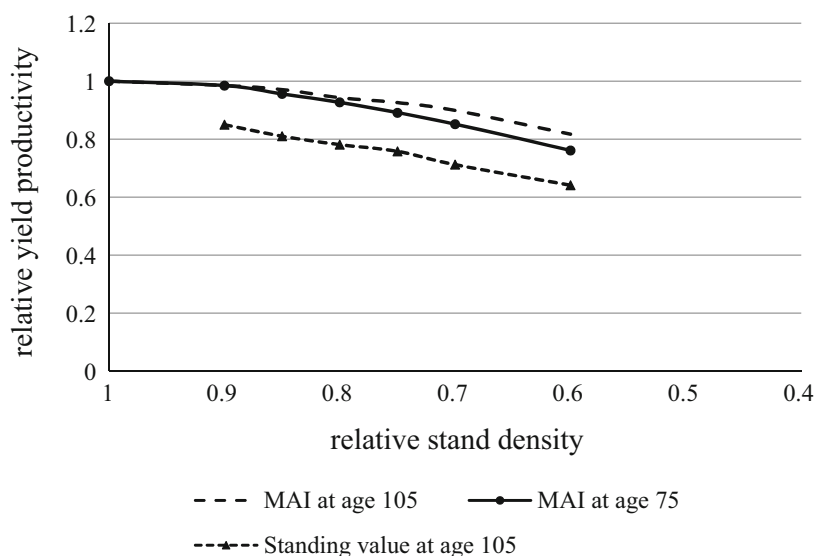

Fig. 7 Simulated relative value productivity in relation to stand density

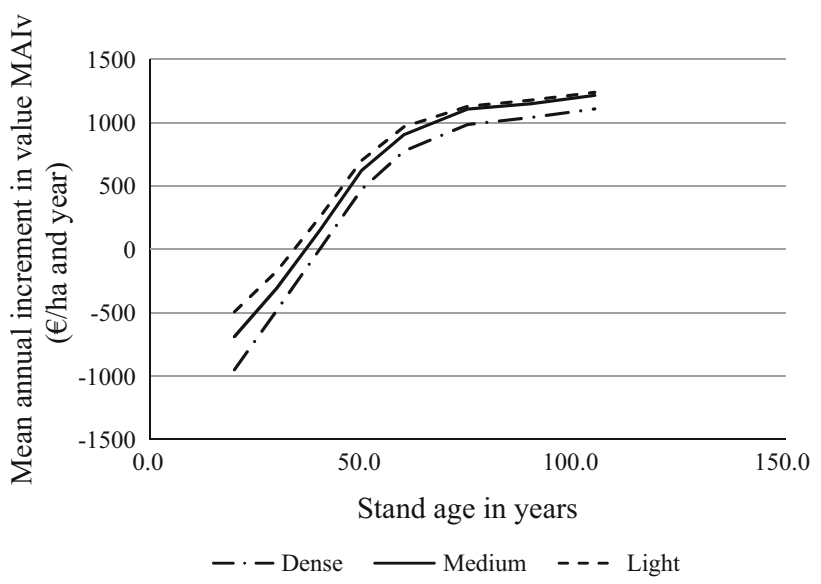

Fig. 8 Simulated mean net value (MAIv) for different spacing at stand establishment

trees) should be considered as an interesting way of adding value. According to the saw mill in Switzerland specialised in Douglas-fir (Company Küng Broth.; personal communication), the selling prices for correctly pruned Douglas-fir logs could readily be $€ 80$ more per $\mathrm{m}^{3}$ than for not pruned timber. With our assortment simulator, we determined the additional value of $100 \mathrm{crop}$ trees/ha at target age of 105 years, when distributed according to the SiWaWa model, which amounted to $€ 43,679$. The cost of pruning until $12 \mathrm{~m}$ in height is $€ 2,083$, performed in two steps, with the alpinist method using a climbing harness and rappelling. The cost of this silvicultural measure represents only $5 \%$ of the added value at the end of production. Thus pruning leads to a surplus-value of $€ 41,569$, i.e. $+47 \%$ of the final net value or $+31 \%$ of the total net yield value. Without doubt, pruning is a significant measure for adding value, usually contributing more than every thinning procedure. 
Influence of starting time of thinning on net profitability

The conventional wisdom in classical silviculture is that thinning should be applied early, frequently and moderately. The higher labour costs for harvesting operations today mean this belief must be questioned. To address this issue, we launched a last set of simulations around the mean variant SDI $80 \%$. This figure refers to an early thinning variant with bold interventions in the young stages (varying from $30 \% G$ at beginning to 22 after), after 20, 30 and 40 years, and one after 55 years so that the SDI at age 105 is equal to that in the reference regime. In comparison, with a delayed variant, starting slowly at age 45 $\left(d_{\mathrm{g}}=31 \mathrm{~cm}\right)$ and with increasing thinning intensity, the same SDI can be attained at age 105 .

With both the early and the delayed thinning regime, the MAIv is about $10 \%$ less than with a regular constant variant (13\% for early and $10 \%$ for delayed; Fig. 9). The net value of the remaining stand at age 105 is $+18 \%$ for the early regime and $-4 \%$ for the delayed one. The difference of $€ 20,046$ represents the effects of the different timings of the start of thinning on stand development. The net value, MAI, culminates earlier with the delayed regime (at 80 years), whereas the MAI for the early regime is still increasing at 80 years.

\section{Discussion}

The most striking finding of this study is the importance of the stocking density (so-called mass effect), which influences the net merchantable value much more than a girth effect, as consequence of spacing through thinning. This finding is not new in terms of volume yield. Since Assmann's (1954) study, we have known that reducing the stand density at best only very slightly increases, in the long run, the relative total yield in volume. More usual is a reduction in yield, which is more accentuated as the

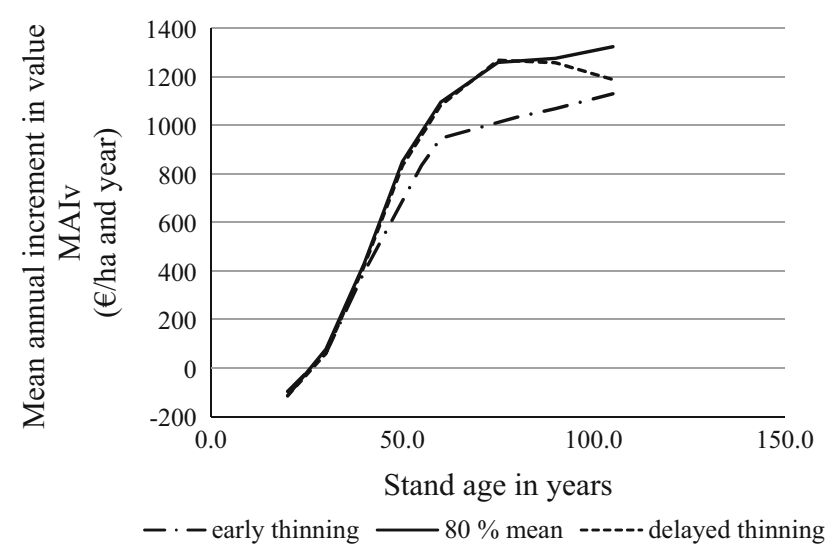

Fig. 9 Simulated mean net value (MAIv) for different time modulations of thinning interventions stocking is diminished. This corroborates similar results of American thinning studies on Douglas-fir (e.g. Oliver and Murray 1982). Translated into value, this effect appears clearly because larger dimensions increase the merchantable value in a nonlinear manner. In our case, we calculated with a price reduction of $4 \%$, respectively, $7 \%$ for large timber classes (class 4 and 5, e.g. with mid-diameter $>50 \mathrm{~cm}$ ). Thus the main factors that increase the value of timber are large dimensions and high stocking.

The volume productivity (MAI volume) culminates at tree ages between 50 and 80 years (results not shown) and diminishes only very slightly after that. In contrast, the net value productivity is still increasing at age 105 (Figs. 6, 8). This means that, from the point of view of biological productivity, the optimal term of production has still not been reached when the stands are 100 years old. Therefore we support the conclusion of Curtis et al. (1977) that "results on current growth rate... cast serious doubts on the wisdom of short rotations. Moderate extension of rotations... considerably increase both volume and value of timber while creating stands and landscapes with high nontimber forest value". Thus whether to aim for large or smaller timber dimensions is, particularly in the case of Douglas-fir, clear: conditionally of enough timber quality, large timber is much more interesting than small timber. This is particularly so because the proportion of heartwood (pithiness) in large timber clearly affects quality.

This does not mean that only moderate thinning should be performed. The expected compensatory increment transfer to a reduced number of future trees does not occur in the manner expected. This transfer still works as a simulation of different starting points in time for the thinning shows. The intuitive belief of silviculturists that if thinning is performed at the right time, then the stand will respond well, still seems correct. This should not lead to excessive interventionist zealousness but should be moderated by taking into consideration cost efficiency, for instance, by applying the principles of biological rationalisation. This is particularly true for interventions in young stands, which are often extremely expensive. Otherwise planning the thinning regime should take into consideration strategic factors such as how best to ensure an appropriate renewal, preferably with natural regeneration decentralised in time and space. Here ensuring the stability of mature stands is essential. Another option is to change the production strategy, for instance, into a plenter system, which appears to work well (see below).

\section{Conclusions}

To understand the effectiveness of thinning, a very differentiated approach is needed to take into consideration 
the differences in individual trees' evolution potential, which depends on their social position. For reliable recommendations about the best approach to thinning, further long-term research is needed that considers the overall multiple use objectives of the silvicultural interventions.

On the operational (tactical) level

A striking result of the Neuendorf trial is that the maximum diameter is not influenced by the thinning treatment (Fig. 4). This is a very important finding, particularly considering the point of natural (genetic determined) variability of the individual development potential. Analysing un-thinned young stands, Ammann (2004) demonstrated that we will always find a large enough proportion of individuals in a tree population that are sufficiently vital to dominate in the stand spontaneously. They will remain stable, and advance in their social dominant position, developing good crown characteristics and stem form even after 40-60 years. Thus, not every tree needs the same amount of thinning help. Only socially less autonomous individuals need more crown-releasing interventions. Reducing the number of crop trees to the minimum necessary at the end of production and clearing them according to their real individual needs would allow a substantial reduction in the number of trees to be removed. The effect on stand development would be the same and the stand stability immediately after the intervention would not be affected. Furthermore, when thinning very young stands (pole stage) cutting the trees to be removed but leaving them standing, i.e. slant cutting (see Schütz 2006) can greatly reduce the cost to 10 or $20 \%$ of the normal cost. On the other hand, if thinning is applied too regularly to too many candidates, the socialisation of the stand may become to homogenised, which is counterproductive if the space and development potential is to be used efficiently (Ammann 2013). A so-called bio-rationalisation may help to considerably improve profitability. Pardé (1981), Preuhsler and Schmidt (1989) and Utschig (2000) observed that the most dominant tree class does not grow differently under different thinning interventions.

We therefore suggest delaying the first thinning intervention until the natural social structure of the stand has become well established, at say, an age of 25-30 years. Such interventions should not be too heavy, at least not for the whole stand, because the individual stability of trees in this phase is weak due to their slender stems, and they may be damaged by snow last. Reducing too extensively and regularly the stand closure would be destabilising. As Ivanov (2007) demonstrated experimentally, determinant for the stem breakage is less the slenderness of the stem than the asymmetry of the crown because the breakage process comes from a buckling phenomenon. Thus situative thinning (Schütz 2006) is recommended, i.e. only around crop trees differentiate in freeing sharpness according to the natural social autonomy of the crop tree considered. This represents the right compromise between ensuring good crown development and stability. Solid silvicultural skills are required for the first social conditioning operation which is essential to ensure the stand receives an appropriate biological "kick" to develop social autonomy. The following interventions can then be done using mechanical tools such as a harvester, with their timing and magnitude (strength) depending on the goals of the treatment. Even though the most moderate trajectory may produce the most increment, it may not be wisest choice.

\section{On the strategic level}

A thinning regime should not only be planned for just one generation but the management in the long term, including how it should be renewed, must also be considered. It is important, for example, to consider on how to deal with risk, particularly before and during regeneration, because without enough stability, a planned delayed regeneration could lead to a failure. In mature stands, the main risks in temperate Europe are essentially storms with relatively low recurring probability (Schütz et al. 2006; Mason 2002). When releasing the canopy closure for regeneration, the stand stability could be endangered. The stability depends then on the individual stem properties, and how resilient the stem's shape is to breaking and root anchorage to snapping. Vanomsen (2006) showed experimentally in a 90-year-old spruce thinning trial that, with a bold thinning regime (SDI 0.45), the resistance to snapping of dominant $35 \mathrm{~m}$ high trees was $45 \mathrm{KN}$ compared with $27 \mathrm{KN}$ for a moderate thinning (SDI 0.80), i.e. it was 1.7 times more resilient. The main reason was that the deadweight of the rooting ball was in similar proportions in both thinning regimes. This shows that a good thinning regime improves a stand's stability and should be preferred to a rather moderate intervention, even if it does not result in an optimal MAIv.

\section{The plenter forest system}

Application of the plenter system to Douglas-fir allows an interesting discussion about compensation effects. Schütz and Pommerening (2013) have recently shown that the plenter system is absolutely applicable to Douglas-fir, although only if the density of the stand closure is relatively low, i.e. with a basal area of $\sim 27 \mathrm{~m}_{2 /}$ ha (SDI 0.30). Douglas-fir recruitment is more light-demanding than other conifers like silver fir and Norway spruce. It is interesting that this occurs without a substantial increment reduction. Our assortment simulator calculated the net value increment for the plenter equilibrium to be $€ 1,153$ /ha and year. This is only about $5 \%$ less than the MAIv for the reference even-aged system (with SDI 0.8), if stand establishment costs are deducted in the even-aged 
system. It does not include the value of the remaining stand in the plenter system, because the productivity of the plenter system is inherently equal to what is currently removed and remains constant in time. Moreover, preserving the remaining stand is a precondition for production. However, if we add this value $(€ 17,450)$, distributed over the same reference period of 105 years, the productivity of the plenter system is $8.6 \%$ higher than that of the even-aged system.

This shows that even with a marked reduction in the stand density, the whole net productivity is maintained. This is due to the productive advantages of the plenter system, which produces $30 \%$ less small timber and much more large timber (Schütz 1986). Thus economically, the difference in income is considerable. Another major economic advantage of the plenter system is that it relies on natural renewal which is for free and involves no extra management costs (Lemm et al. 2013).

Acknowledgments We are extremely grateful to Dr. Robert O. Curtis, the former silviculturist at the PNW-Experiment station Portland USA and Dr. Doug Maguire OSU Corvallis for letting us have access to the data from the LOGS trials.

\section{References}

Abetz P (1975) Eine Entscheidungshilfe für die Durchforstung von Fichtenbeständen. Allg Forst Z 30:666-667

Ammann P (2004) Untersuchung der natürlichen Entwicklungsdynamik in Jundwaldbeständen; Biologische Rationalisierung der waldbaulichen Produktion bei Fichte, Esche, Bergahorn und Buche. PhD thesis, ETH no. 15761. Skaker

Ammann P (2013) Erfolg der Jungwaldpflege im Schweizer Mittelland? Analyse und Folgerungen (essay). Schw Z Forstwes 164(9):262-270

Assmann E (1954) Grundflächenhaltung und Zuwachsleistung Bayerischer Fichten Durchforstungsreihen. Forstw Cbl 73(9/ 10):257-271

Bailey JD, Tappeiner JC (1998) Effects of thinning on structural development in 40- to 100-year-old Douglas-fir stands in western Oregon. For Ecol Manag 108:99-113

Bastien Y (1997) Pour l'éducation du hêtre en futaie claire et mélangée. Rev For Fr 49(1):49-68

Bégin J (1992) Productivité du Douglas vert (Pseudotsuga menziesii [Mirb.] Franco var. menziesii Franco) en relation avec des caractéristiques stationnelles. Mitteilungen der Eidgenössischen Forschungsanstalt für Wald, Schnee und Landschaft 67(2): $175-313$

Broillard Ch (1901) Des résultats de l'éclaircie. Rev Eaux For 40:1-10

Charru M, Seynave I, Morneau F, Rivoire M, Bontemps JD (2012) Significant differences and curvilinearity in the self-thinning relationship of 11 temperate tree species assessed from forest inventory data. Ann For Sci 69:195-205

Curtis RO, Marshall D, Bell JF (1977) LOGS, a pioneering example of silvicultural research in coastal Douglas-fir. J For 95(7):19-25

Curtis RO, Clandenen GW, Reukema DL, DeMars DJ (1982) Yield tables for managed stands of coastal Douglas-fir. General technical report PNW-GTR-135
Dagnélie P, Palm R, Rondeux J, Thill A (1999) Tables de cubage des arbres et des peuplements forestiers. Les Presses Agronomiques de Gembloux, Gembloux

Drew TJ, Flewelling JW (1979) Stand density management: an alternative approach and its application to Douglas-fir plantations. For Sci 25(3):518-532

Frutig F, Thees O, Lemm R, Kostadinov F (2009) Holzernteproduktivitätsmodelle HeProMo; Konzeption, Realisierung, Nutzung und Weiterentwicklung. In: Thees O, Lemm R (eds) Management zukunftsfähiger Waldnutzung: Grundlagen, Methoden und Instrumente. Vdf Hochschulverlag, Birmensdorf, pp 441-466

Hiley WE (1956) Economics of plantations. Faber and Faber Ltd, London $216 p$

Ivanov DE (2007) Stabilité et résistance individuelle et collective et phénomène de désintégration collective face aux sollicitations de neige lourde au sein de peuplements de pin sylvestre (Pinus sylvestris $\mathrm{L}$.). $\mathrm{PhD}$ thesis, ETH no. 17513

Knoke T (1998) Die Stabilisierung junger Fichtenbeständen durch starke Durchforstungseingriffe; Versuch einer ökonomischen Bewertung. Forstarchiv 69:219-226

Lemm R, Holm S, Thees O (2013) Bessere Produktions- und Nutzungsentscheide mit dem Sortierungssimulator SorSim. Schw Z Forstwes 164:301-309

Mason WJ (2002) Are irregular stands more windfirm? Forestry 75:347-355

Newnham RM (1988) A modification of the Ek-Payandeh nonlinear regression model for site index curves. Can $\mathrm{J}$ For Res $18: 115-120$

Oliver CD, Murray MD (1982) Stand structure, thinning prescriptions, and density indexes id a Douglas-fir thinning study, Western Washington, U.S.A. Can J For Res 13:126-136

Pardé J (1981) De 1882 à 1976/80 les places d'expérience de sylviculture du hêtre en forêt domaniale de Haye. Rev For Fr 33:41-64

Payandeh B (1974) Nonlinear site index equations for several major Canadian timber species. For Chron 50(5):194-196

Pretzsch H, Biber P (2005) A Re-evaluation of Reineke's rule and stand density index. For Sci 51(4):304-320

Preuhsler T, Schmidt R (1989) Beobachtungen auf einem spät durchforsteten Fichten-Versuch. Forstwiss Cbl 108:271-288

Reineke LH (1933) Perfecting a stand density index for even-aged forests. J Agric Res 46:627-638

Reventlow CDP (1801) Einsammlung nützlicher Erfahrung bezüglich der Vegetation und der Erziehung der Bäume und wie diese Erfahrung bei der Bewirtschaftung der Wälder verwendet werden können um den grössten Vorteil aus den Forsten zu gewinnen. Dän. Gesellsch. Wissenschaft

Roth B, Bucher HU, Schütz JP, Ammann P (2001) Ringeln; Alte Methode neu angewendet. Wald und Holz 82(4/01):38-41 and (5/01):30-31

Schädelin W (1926) Bestandeserziehung. Schweizerische Zeitschrift fur Forstwesen 77 (1):1-15, 33-44

Schädelin W (1934) Die Durchforstung als Auslese und Veredlungsbetrieb höchster Wertleistung. Haupt, Bern

Schütz JP (1975) Dynamique et conditions d'équilibre de peuplements jardinés sur les stations de la hêtraie à sapin. Schw Z Forstwes 126(9):637-671

Schütz JP (1986) Geschichtlicher Hergang und aktuelle Bedeutung der Plenterung in Europa. Allgemeine Forst und Jagdzeitung 165:106-114

Schütz JP (1999a) Erfassung der situative Konkurrenz in gleichförmigen Fichtenbestockungen aufgrund physiologisch orientiertem Positionsparameter. In: Tagungsbericht Jahrestagung Deutscher Verband forstlicher Forschungsanstalten. Sektion Ertragskunde, 17-19. Mai 1999 in Volpriehausen, pp 70-78 
Schütz JP (1999b) Neue Waldbehandlungskonzepte in Zeiten der Mittelknappheit; Prinzipien einer biologisch rationellen und kostenbewussten Waldpflege. Schw Z Forstwes 150(12):451-459

Schütz JP (2003) Die situative Durchforstung: ein an der Extensivierung der Kosten orientiertes Durchforstungskonzept. In: Brang P (ed) Biologische Rationalisierung im Waldbau. Tagungsband Jahrestagung der Sektion Waldbau im Deutschen Verband forstlicher Forschungsanstalten, Birmensdorf, 10-12 Sept 2003, pp 4-13

Schütz JP (2006) Opportunities and strategies of biorationalisation of forest tending within nature-based management. Studia Forestalia Slovenica 126:39-46

Schütz JP, Pommerening A (2013) Can Douglas fir (Pseudotsuga menziesii (MIRB.) FRANCO) sustainably grow in complex forest structures? For Ecol Manag 303:175-183

Schütz JP, Zingg A (2007) Zuwachsprognose nach der sozialen Hierarchie im Entwicklungs- und Wuchsmodell SiWaWa. In: Nagel J (ed) Jahrestagung Deutscher Verband forstlichen Forschungsanstalten, Sektion Ertragskunde, Göttingen, pp 180-187

Schütz JP, Zingg A (2010) Improving estimations of maximum stand density by combining Reineke's size-density rule and the yield level, using the example of spruce (Picea abies (L.) Karst.) and European beech (Fagus sylvatica L.). Ann For Sci 67(5): $507-518$
Schütz JP, Götz M, Schmid W, Mandallaz D (2006) Vulnerability of spruce (Picea abies) and beech (Fagus sylvatica) forests stands to storms and consequences for silviculture. Eur $\mathrm{J}$ For Res 125:291-302

Utschig H (2000) Wachstum vorherrschender Buchen in Abhängigkeit von Standort und Behandlung. Forts und $\mathrm{Holz}$ 55(2):44-50

Utschig H (2002) Analyse der Standraumökonomie von Einzelbäumen auf langfristig beobachteten Versuchsflächen; Methoden, Programmentwicklung und erste Ergebnisse. Forstwiss Cbl 121:335-348

Vanomsen P (2006) Der Einfluss der Durchforstung auf die Verankerung der Fichte hinsichtlich ihrer Sturmresistenz. PhD thesis, ETH no. 16532

Wilhelm G, Rieger H (2013) Naturnahe Waldwirtschaft mit der QD Strategie. Ulmer, Berlin

Wykoff WR (1990) A basal area increment model for individual conifers in the Northern Rocky Mountains. For Sci 36:1077-1104

Wykoff WR, Crookston NL, Stage AR (1982) User's guide to the Stand Prognosis model. USDA Forest Service, General technical report INT-133, Ogden, Utah 